\title{
IMPLEMENTASI KEBIJAKAN PERATURAN BUPATI NO 20 TAHUN 2019 TENTANG SISTEM ONLINE PAJAK DAN RETRIBUSI DAERAH DI KECAMATAN MARITENGNGAE KABUPATEN SIDENRENG RAPPANG
}

\author{
1)Ridwan Syahrir, ${ }^{2)}$ Lukman, ${ }^{3)}$ Madaling \\ AdministrasiPublik, Fakultas IImu Sosial dan IImu Politik Universitas Muhammadiyah SidenrengRappang \\ ridwansyahrir43162011.1a@gmail.com \\ lukmansidrap75@gmail.com
}

\begin{abstract}
Abstrak
Penelitian ini bertujuan untuk mengetahui Implementasi Kebijakan peraturan Bupati no 20 tentang sitem online pajak dan retribusi daerah di Kabupaten Sidenreng Rappang. Populasi dalam penelitian ini berjumlah 213 sedangkan sampel yang diambil sebanyak 21 responden. Tehnik pengambilan sampel yang digunakan yaitu menggunakan rumus Yount. Teknik Pengumpulan data yang digunakan melalui Observasi, Kuesioner (Angket), dokumentasi. Teknik Analisis data yang digunakan adalah analisis deskriptif dengan table frekuensi. Hasil Penelitian ini Menunjukkan bahwa implementasi kebijakan peraturan Bupati no 20 tahun 2019 tentang sistem online pajak dan retribusi daerah di Kecamatan Maritengngae Kabupaten Sidenreng Rappang masuk pada kategori efektif, sebagaimana hasi lolahan data yang menunjukkan kategori "Baik/efektif" dengan persentase $57,82 \%$. Adapun faktor yang paling berpengaruh yaitu Disposisi kebijakan $63,70 \%$, dan hasil terendah adalah pada faktor sumberdaya $53,55 \%$.
\end{abstract}

Kata Kunci: implementasi,komunikasi,sumberdaya,disposisi,struktur birokrasi.

\begin{abstract}
This study aims to determine the Implementation of Regulations Policy No. 20 Regent about the online system of taxes and local levies in Sidenreng Rappang Regency. The population in this study amounted to 213 while the samples taken were 21 respondents. The sampling technique used is using the Yount formula. Data collection techniques used through observation, questionnaires, documentation. The data analysis technique used is descriptive analysis with a frequency table. The results of this study indicate that the implementation of Bupati regulation regulation no 202019 on the online system of regional taxes and user charges in the Maritengngae District of Sidenreng Rappang Regency is in the effective category, as the result of data processing shows the category of "Good / effective" with a percentage of $57.82 \%$. The most influential factor is the policy disposition of $63.70 \%$, and the lowest yield is the resource factor of $53.55 \%$.
\end{abstract}

Keywoard: implementation, communication, resourse, disposition, bereaucratic structure. 


\section{A. PENDAHULUAN}

Pajak (dari bahasa Latin taxo; "rate") adalah iuran rakyat kepada negara berdasarkan undang-undang, sehingga dapat dipaksakan, dengan tidak mendapat balas jasa secara langsung. Perpajakan di Indonesia didasarkan pada Pasal 23A UUD 1945, dimana pajak adalah kontribusi yang dibayarkan oleh semua warga negara indonesia, baik lokal maupun asing dan warga yang tinggal 120 hari diwilayah indonesia dan dua belas bulan lamanya. Pajak dipungut berdasarkan norma-norma hukum (sesuai dengan perubahan ketiga

UUD 1945 pasal 23A ) untuk menutup biaya produksi barang dan jasa kolektif untuk mencapai kesejahteraan umum. Khususnya di indonesia sudah tersedia berbagai sistem layanan pajak online yang tentunya memudahkan masyarakat dalam membayar pajak. Peraturan Bupati Sidenreng Rappang tentang sistem online pajak daerah dan retribusi daerah didalamnya memuat pasal tentang pajak Restoran yang mewajibkan setiap pemilik usaha yang masuk dalam kategorinya dikenakan wajib pajak. Peraturan tersebut merupakan amanah dari Peraturan Daerah (Perda) kabupaten sidrap no 10 tahun 2011 tentang pajak restoran,ini merupakan salah satu langkah pemerintah untuk memaksimalkan pendapatan daerah khususnya dalam pajak demi meningkatkan pemertaaan pembangunan dan meningkat kesejahteraan masyarakat kabupaten sidrap secara umum.

Aturan terkait pajak restoran ini diatur dalam Peraturan Bupati (PERBUB) No.20 Tahun 2019 Tentang Sistem Online Pajak dan Retribusi Daerah Kabupaten Sidenreng Rappang dalam bab III pasal 3 ayat 1 huruf $b$ yang selanjutnya dijelaskan dalam ayat 3 memuat 6 huruf ;

1. Penjualan makanan dan/atau minuman;

2. Pembayaran pemakaian ruang rapat atau ruang pertemuan di restoran (Romm Charge);

3. Service charge;

4. Minuman charge/ first drink charge;

5. Pembayaran jasa boga /catering; dan

6. Data transaksi lainnya yang berkaitan dengan pembayaran pajak pajak restoran.

Berdasarkan enam indikator dari Perbub diatas, 3 diantaranya sudah terealisasi dan 3 lainnya belum terealisasi.
Berdasarkan fakta

indikator diantaranya;

1. Penjualan makanan dan/atau minuman

2. Service charge.

3. Data transaksi lainnya yang berkaitan dengan pembayaran pajak pajak restoran.

Sementara George Edward III dalam bukunya Implementing Publik Polyce (1980) mengatakan ada empat indikator agar suatu implementasi kebijakan berjalan dengan baik,yaitu,Communication(Komunikasi), Reso urse(Sumberdaya),Disposition (Disposisi), dan Beraucration Structure (Struktur Birokrasi). Secara kontiniutas tentunya kebijakan ini akan mamatikan usaha restoran selain dari tarifnya yang tinggi, juga sanksi yang dikenakan adalah penutupan dan pencabutan surat izin usaha ketika restoran tidak menggunakan alat yang telah disediakan oleh Pemerintah Daerah (Pemda) setempat.Namum satu hal yang menarik calon peneliti adalah keberadaan Peraturan Bupati (Perbub) ini masih kurang diketahui oleh masyarakat umum para komsumen atau pembeli,maka dari itu penulis tertarik mengambil judul Implementasi Kebijakan Peraturan Bupati No 20 Tahun 2019 Tentang Sistem Online Pajak Daerah Dan Retribusi Daerah Di Kecamatan Maritengngae Kabupaten Sidenreng Rappang dengan tujuan untuk mengetahui implementasi Peraturan Bupati No 20 Tahun 2019 Tentang Sistem Online Pajak Daerah Dan Retribusi Daerah di Kecamatan Maritengngae Kabupaten Sidenreng Rappang dan untuk mengetahui Faktor apa yang mempengaruhi implementasi Peraturan Bupati No 20 Tahun 2019 Tentang Sistem Online Pajak Daerah dan Retribusi Daerah di Kecamatan Maritengngae Kabupaten Sidenreng Rappang.

Dunn (Tahir, 2014) memberikan argumennya tentang implementasi kebijakan sebagai berikut: policy implementatation is essentially a practical activity, as distinguished from policy formulation, which is essentilly theoretical. Sehubungan dengan sifat praktis yang ada dalam proses implementasi kebijakan maka ia mendefinisikan implementasi berkaitan dengan proses politik dan administrasi. Terkait hal tersebut Ada beberapa teori mengenai implementasi kebijakan publik dari para ahli. Ripley dan Franklin dalam (Agustino, 2014) menulis tentang three 
conceptions relating to successful implementation. Donald Van Metter dan Carl Van Horn dalam (Arifin Tahir,2014) yang mempengaruhi kinerja kebijakan yaitu:

1. Komunikasi antar organisasi dan aktivitas pelaksana.

2. Karakteristik agen pelaksana.

3. Lingkungan Ekonomi, Sosial, dan Politik.

4. Sikap/kecendrungan (disposisi) pelaksana.

Menurut George Edward III dalam Widodo (2010:96) terdapat 4 faktor yang mempengaruhi keberhasilan atau kegagalan implementasi kebijakan antara lain yaitu:

1. Komunikasi. Menurut Edward III dalam Widodo (2010:97), komunikasi diartikan sebagai proses penyampaian informasi dari satu orang ke orang lain". Informasi tentang kebijakan publik menurut Edward III dalam Widodo (2010:97) harus tersampaikan kepada semua yang terlibat agar para pelaku kebijakan dapat mengetahui apa yang harus mereka persiapkan dan lakukan untuk menjalankan kebijakan tersebut sehingga tujuan dan sasaran kebijakan dapat dicapai sesuai dengan yang diharapakan. Adapun ketiga dimensinya yaitu, transmisi,kejelasan, dan konsistensi.

2. Sumber daya. Edward III dalam Zainuddin (2017:214) mengemukakan bahwa implementasi berjalan efektif adalah konsistennya pemerintah dalam mengimplementasikan suatu kebijakan dengan dukungan sumberdaya yang mencukupi, maka implementasi akan efektif meliputi; staff, informasi, otoritas, dan fasilitas. Adapun dimensinya adalah manusia, anggaran, peralatan, dan kewenangan.

3. Disposisi. Adapun Disposisi menurut Edward (Widodo,2010:104) dikatakan sebagai "kemauan, keinginan dan kecenderungan para perlaku kebijakan untuk melaksanakan kebijakan tadi secara sungguh sungguh sehingga apa yang menjadi tujuan kebijakan. Adapun dimensinya adalah pengangkatan birokrasi dan insentif.
4. Struktur birokrasi. Ripley dan Franklin dalam Widodo (2010) mengidentifikasi karakteristik birokrasi sebagai hasil pengamatan terhadap birokrasi di Amerika Serikat, yaitu: tujuan, netral dan hirarki.

\section{B. METODE PENELITIAN}

Penelitian ini adalah sesuatu yang dilakukan secara terencana dan tersusun dengan sistematis untuk mendapat jawaban mengenai fenomena yang ditemukan, maka dari itu jenis penelitian ini adalah kuantitatif dengan metode pendekatan deskriptif. Adapun jumlah populasi pada penelitian ini adalah sebanyak 213 orang, dan yang menjadi sampel penelitian ada yaitu 21 orang dengan tehnik pengambilan sampel menggunakan rumus Yount. Tehnik pengumpulan data yang digunakan adalah observasi, kuisioner (angket) dan dokumentasi. Tehnik analisis data yang digunakan yaitu data diolah melalui tabel frekuensi untuk mendeskripsikan lebih jelas mengenai indikator penelitian.

\section{HASIL DAN PEMBAHASAN}

Implementasi Kebijakan Peraturan Bupati No 20 Tahun 2019 Tentang Sistem Online Pajak Daerah Dan Retribusi Daerah Di Kecamatan Maritengngae Kabupaten Sidenreng Rappang

1. Komunikasi. Adanya sosialisasi yang dilakukan oleh pemda terkait dengan pemungutan pajak dengan sistem online,dengan hasil persentase $70,4 \%$. Adanya arah, sasaran, maksud dan tujuan dilakukannya pemungutan pajak secara online, dengan hasil persentase $51 \%$. Adanya penyampaian yang dilakukan pemda terkait dengan pajak online dengan kenyataan yang terjadi dilapangan, hasil persentase adalah 56\%. Komunikasi kebijakan terhadap Implementasi Kebijakan Di Kecamatan Maritengngae Kabupaten Sidenreng Rappang yaitu $59,13 \%$ dikategorikan baik.

2. Sumber daya. Adanya lembaga pemda yang melakukan sosialisasi kebijakan dalam hal ini Badan Pengelolah Keuangan Daerah Sidenreng Rappang adalah 78\%. Adanya pembagian alat kepada wajib pajak tampa adanya indikator yang jelas adalah $45 \%$. Adanya penggunaan anggaran yang digunakan untuk pembelian MPOS sebagai alat pemungutan pajak online adalah $50,4 \%$. 
Adanya kehendak pemerintah menetapkan tarif $10 \%$ untuk setiap pembelian makanan/minuman di restoran wajib pajak adalah $40,8 \%$. Sumberdaya kebijakan terhadap Implementasi Kebijakan Peraturan Bupati No 20 Tahun 2019 Tentang Sistem Online Pajak Dan Retribusi Daerah Di Kecamatan Maritengngae Kabupaten Sidenreng Rappang yaitu $53,55 \%$ dikategorikan baik.

3. Disposisi. Adanya tim pengawas yangdiangkat oleh Pemda terhadap penggunaan alat MPOS adalah $64,6 \%$. Insentif yang ditetapkan Pemda terhadap penggunaan alat MPOS adalah $62,8 \%$. Disposisi kebijakan terhadap Implementasi Kebijakan Perbup No 20 Tahun 2019 Tentang Sistem Online Pajak Dan Retribusi Daerah Di Kecamatan Maritengngae Kabupaten Sidenreng Rappang yaitu 63,70\%dikategorikan baik.

4. Struktur birokrasi. Adanya penetapan tujuan dari penggunaan alat MPOS adalah $56 \%$. Adanya sikap pemerintah memberlakukan sistem pajak online secara tidak merata kepda setiap restotran adalah $44,8 \%$. Adanya hubungan antara pemerintah daerah dan kecamatan terkait sistem pajak online adalah $64 \%$. Struktur birokrasi kebijakan terhadap Implementasi Kebijakan Peraturan Bupati No 20 Tahun 2019 Tentang Sistem Online Pajak Dan Retribusi Daerah Di Kecamatan Maritengngae Kabupaten Sidenreng Rappang yaitu 54,93\%dikategorikan baik.

Rata-rata dari hasil persentase dari 5 item pertanyaan pada indikator yang berpengaruh diatas, maka didapat hasil ratarata persentase. Jadi dapat ditarik kesimpulan bahwa dalam indikator ini berada dalam kategori "baik".

\section{KESIMPULAN}

Berdasarkan hasil penelitian yang telah diuraikan pada bab IV, maka dapat ditarik kesimpulan bahwa ;

1. Implementasi kebijakan di Kecamatan Maritengngae Kabupaten Sidenreng Rappang dikategorikan "efektif" dengan persentase $(57,82 \%)$, melihat dari olahan data kuisoner. Dengan persentase tertinggi yaitu pada indikator disposisi $(63,70 \%)$ dan terendah pada indikator sumberdaya ( $53,55 \%)$.
2. Faktor Komunikasi kebijakan diliahat dari indikator Transmisi(70,4 \%), Kejelasan (51\%) , dan Konsistensi (56\%) dikategorikan "efektif " dengan rata-rata presentase $59,13 \%$, melihat dari olahan data kuisioner.

3. Faktor Sumberdaya kebijakan dilihat dari indikator Manusia(78\%), peralatan(45\%), anggaran (50,4\%), Kewenangan(40,6\%) dikategorikan "efektif" dengan rata-rata presentase $(53,55 \%)$, dilihat dari olahan data kuisioner.

4. Faktor Disposisi kebijakan dilihat dari indikator pengangkatan birokrasi( $64,6 \%)$, insentif $(62,8 \%)$ dikategorikan "efektif" dengan rata-rata presentase $(63,70 \%)$ dilihat dari olahan data kuisioner.

5. Faktor struktur birokrasi dilihat dari indikator tujuan ( 56\%) Netral(44,8\%), dan Hirarki (64\%) dikategorikan " efektif" dengan rata-rata presentase $(54,82 \%)$ dilihat dari data olahan kuisioner.

\section{E. REFERENSI}

Agustino, L. 2014. . Dasar-Dasar Kebijakan Publik. . Bandung: Alfabeta. .

Ahmad, Jamaluddin. 2015. Metode penelitian administrasi. Toeri dan aplikasi. Yogyakarta: Gava Media. .

Arikunto, Suharsimi. 2015. . Dasar-dasar Evaluasi Pendidikan. Jakarta: Bumi Aksara.

Hartina Tamrin, Muhammad Ikbal, Saifullah. 2016. . Implementasi Kebijakan Peraturan Daerah Nomor 18 Tahun 2016 Tentang Kawasan Tanpa Rokok Di Rumah Sakit Arifin Nu'mang Kabupaten Sidenreng Rappang. S1 (Skripsi). . Perpustakaan.

I Wayan darmawan, A.A. Gede Raka, I Made Mardika. 2019. . Implementasi Program Sistem Informasi Manajemen Kepegawaian (SIMPEG) berbasis web di Badan Kepegawaian dan Pengembangan Sumber Daya Manusia 
(BKPSDM) Kabupaten Badung. S2

(Thesis). . Perpustakaan.

Naudini audia, Regi iksan maulana,Nilsa Dwi Andini, Dine Maigewati. 2019. Implementasi Perda No.16 Tahun 2011 Tentang Retribusi Parkir Dalam Meningkatkan Pendapatan Asli Daerah (Pad) Kota Sukabumi. S1(Skripsi). . Perpustakaan.

Setiawan., Irza. 2019. . Implementasi Peraturan Daerahnomor 28 Tahun 2011 Tentang Pajak Reklame Di Kabupaten Hulu Sungai Utara.S1 (Skripsi). . Perpustakaan.

Sugiyono. 2012. . Metode Penelitian Kuantitatif Kualitatif dan R\&D. . Bandung:: Alfabeta.

-. 2016. . Metode Penelitian Kuantitatif Kualitataif dan Kombinasi (Mixed Methods). Bandung: : Alfabeta.

Susinta sahambangun, Herman Nayoan, Marthen Kimbal. 2019. Implementasi Peraturan Daerah Nomor 4 Tahun 2014 Tentang Pengendalian Dan Pengawasan Minuman Beralkohol Di Provinsi Sulawesi Utara (Studi Kasus Di Kecamatan Malalayang Kota Manado).S1 (Skripsi). . Perpustakaan.

Tahir, A. 2014. . Kebijakan Publik dan Transparansi Penyelenggaraan Pemerintah Daerah. . Bandung: Alfabeta. .

Tentang, Peraturan Bupati No 20 Tahun 2019. 2019. Sistem Online Pajak Daerah dan Retribusi Daerah. Sidenreng Rappang: Sldenreng Rappang.

Widodo, Joko. 2010. . Analisis Kebijakan Publik. . Malang: Bayumedia. .

Zainuddin. 2017. . Teori-Teori Mutakhir Dalam Perspektif IImu Administrasi Publik. . Makassar: Phinatama Media. . 